\title{
Measuring The Quality of Pedagogy Infrastructure in Web Based Instruction Using Learning Object Framework (LORI) to Promoting Student's Writing Skill in Indonesian Language Subject
}

\author{
Taufik Ikhsan Slamet \\ Department of Educational Technology, Faculty of Education, \\ State University of Malang \\ Corresponding e-mail: taufik.ikhsan.tep@um.ac.id
}

\begin{abstract}
Promoting student's communication skill, particularly in writing, has been issue for the past decades. Some researches have been conducted to formulate the framework of learning environment which is developed to engage to describe the wuality and its characters of pedagogy infrastructures in web based instruction based on Learning Object framework. The pedagogy infrastructures involved (a) content quality, (b) learning goal alignment, (c) feedback and adaptation, (d) motivation, (e) presentation design, (f) interaction usability, (g) accesibility, (h) reusability, and (i) standard compliance. Research-based design from secondary school (eight grade of Junior High School 4 Malang) are presented. Key results froom surveys to media reviewr, content reviewer, instructional design reviewer, and students are discussed. The results demonstrate that webbased instruction within writing skill lesso has been well received by students. The patform has been a key enabling students to engage into the learning process, even though this process involved only in individual learning. Consideration of the ther three important stakeholders including media, content, and design reviewer could significantly enrich the wuality of the infrastructures of web base dinstruction.
\end{abstract}

Keywords: Web Based Instruction, Learning Object, MOODLE, SCORM, Writing Skill, Language Acquisition.

\section{INTRODUCTION}

Students in information era are required to establish some critical competencies related digital citizenship, including a) creativity and innovation, b) communication and collaboration, c) research and information fluency, d) critical thinking, problem solving, and decision making, e) digital citizenship, and f) technology operations and concepts. Communication skill point of view has transformed from the basic of human needs into the requirements of existance in digital society. Students who manage to succeed their social skills, both in daily life or in academic settings, create greater networking that supports their future carrer and opportunity to build liveable community. By choosing the highest level of communication, that is writing skill, this research deliberate in explaining pedagogy infrastructures in web based instruction to promoting student's writing skill. The research likely focus on writing skill because of professional and academic success in all disciplines depends, at least in part, upon writing skills (Shih, 2011).

Writing well is not just an option for young people, it is a necessity. Along with reading comprehension, writing skill is a predictor of academic success and a basic requirement for participation in civic life and in the global economy (Graham \& Perin, 2007). Typically writing is taught based on prescribed textbook, where teacher teaches the class a sample of writing in the unit, which usually consists of several sentences describing a person or object. Then, the students are asked to do parallel writing with the help of some guiding questions, which means they just change simply the names, pronoun, number, or the original main information (Rijlaarsdam \& Van den Bergh, 2004).

Besides historical and cultural reasons that can explain the practices of teaching to read before teaching to write or spell, what are the scientific reasons actually given by psycholinguistics and didactics? Does reading lead to writing, or the reverse, or are they both acquired in parallel? In short, is there a strictly 
defined "beginning" of literacy and an order of acquisition between reading and writing/spelling? (Saada etc, 2004). A common explanation for why youngsters do not write well is that schools do not do a good job of teaching this complex skill (Graham \& Perin, 2007).

Previous research proves that if a teacher uses the same writing and speaking exercises over and over again the students are less likely to learn than if the lessons are varied (Elftorp, 2007). With respect to ICT, we are witnessing the rapid expansion and proliferation of technologies that are less about "narrowcasting", and more focussed on creating communities in which people come together to collaborate, learn and build knowledge (McLoughlin \& Lee, 2007). Since the early 1980s, writing theorists and instructional designers have envisioned digital "writing environments" that would support writing processes (Palmquist, 2005).

The idea of conducting computer technology into practicing writing skill to students in the classroom context has a long sophisticated story of development. In the early $1980 \mathrm{~s}$, as personal computers began to infiltrate writing centers and writing classrooms, scholars began to consider how they might extend word processing and computer-aided instruction (CAI) software to create a more supportive environment for writers and writing students (Palmquist, 2005). There are some evidences related positive impact of information technology utilization to improving writing skills. A research conducted by Mak \& Coniam (2008) in Hong Kong secondary school generates a conclusion that students produced substantially more text than the 150 words per month expected of them.

Not only they produce a greater quantitiy of text, but also they produce text that would be coherent and accurate. It is the sociability aspects that have the most potential for enhancing education. These aspects are able to support three ingredients or activities that characterise learner-centred instruction, namely: (i) support for conversational interaction; (ii) support for social feedback; and (iii) support for social networks and relationships between people (Boyd, 2007). Learning environment supported information technology should be built in the framework of pedagogy and digital competencies. In this study, there will be ground-breaking of pedagogy infrastructure within web based instruction through learning object framework.
Learning environment based information technology, e.q. web based learning and mobile learning, provide broad access to learning resources and highly-rapid communication to networked society. These advantages benefit students to engage in high level of cognitive skill, such us brainstorming, discussing, analyzing, evaluating, and creating. For the purpose of writing skill, web based instruction support students to a big number of reading materials that delivered in various types of multimedia. This approach not only facilitates different types of learning style based on student characteristics, but also guide them to the various meaningful experiences when engaging to the materials. In an online text-based environment, such us webbased writing, social presence that is based on the concept of emmediacy to learning materials is described as the ability of learners to project themselves socially and emotionally as real people in an online learning community (Garrison, 2007).

\section{MATERIALS AND METHODS}

This study conducted research and development model (Borg \& Gall, 1983) that involves 10 steps of developments, including a) research and information collecting, b) planning, c) develop preliminary form of product, d) preliminary field testing, e) main product revision, f) main field testing, g) operational product revision, h) operational field testing, i) final product revision, and $\mathrm{j}$ ) dissemination and implementation. Adaptation has been made to fulfill the needs of study, a few steps have been changed signifantly in order to collect the proper data that fit to the research context. The diagram bellow represents how study be implemented:

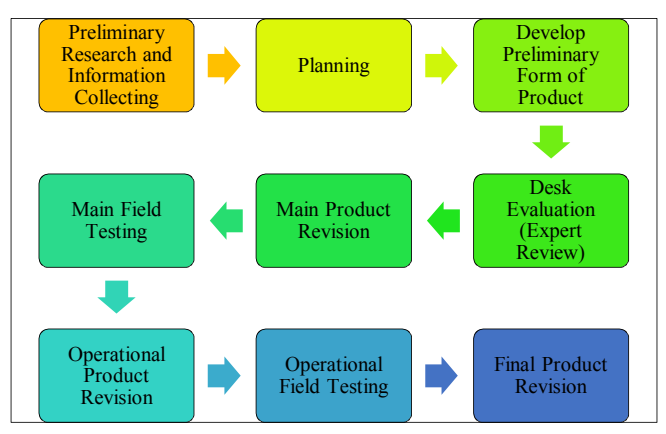

Figure 1. Procedures of the study 
This paper only review the result of evaluation from step desk evaluation and operational field testing. Desk evaluation is the step when the prototype of web-based instruction be evaluated by experts. The step resulted both in quantitative and qualitative data according aspects on learning object framework.

LORI may be used for either individual or panel reviews. When used by a review panel, it is recommend the convergent participation model for collaborative evaluation (Nesbit, Belfer, \& Vargo, 2002). Results should be presented as a set of averaged ratings, one per item, and may be summarized as a single average covering all items used in the evaluation. In this step, parallel evaluation of learning object framework is obeyed. Each expert only reviewed particular aspects related to their expertise, considering their focus of knowledge and undestranding about specific part of the prototype.

To address comprehensive measurement of pedagogy infrastructure in web based instruction, learning object review instrument (LORI) is tested to a group of 8th grader (n: 34) of Junior High School 4 Malang (SMPN 4 Malang). After completing three lesson of writing Indonesian literacy through the prototype with guiding help from teacher and researcher, students are inquired to answer 6 out of 9 criterias in learning object framework. Each criteria generally consists of four questions with LORI scale, in addition, there is an open question to collect qualitative suggestions from students in the end of instrument.

The learning object review instrument is described bellow:

Table 1. learning object review instrument

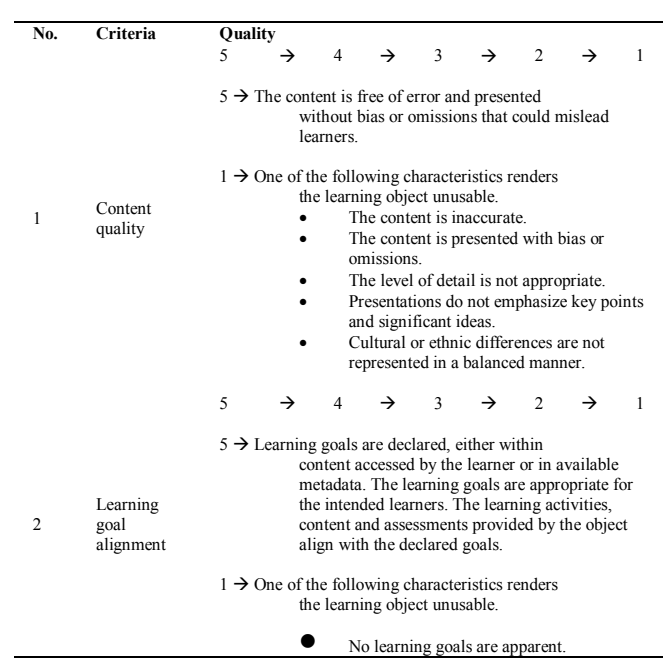

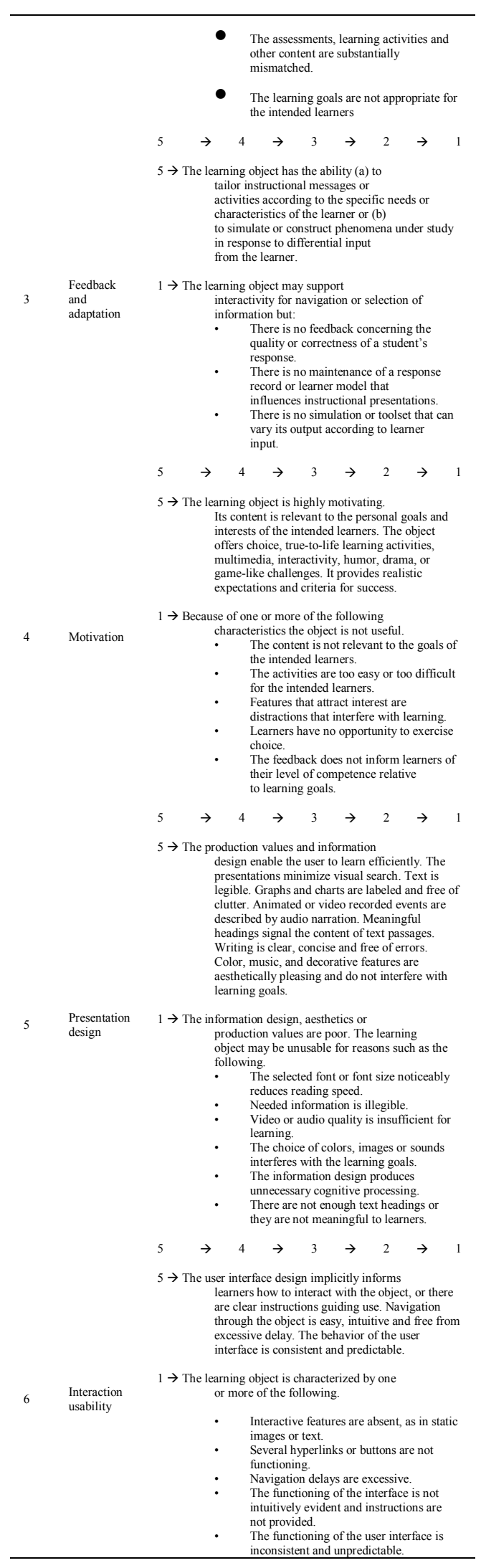

For each item, quality is evaluated on a rating scale consisting of five levels. If the item 
is judged not relevant to the learning object, or if the reviewer does not feel qualified to judge that criterion, then the reviewer may opt out of the item by selecting "not applicable". The reliability of LORI was investigated by Vargo, Nesbit, Belfer and Archambault (2003). LORI rating scale is developed with a similar perspective with Likert rating scale, it is substantialy prescribed students perception towards the pedagogy infrastructures. Bellow is representative to scale the measurement on LORI.

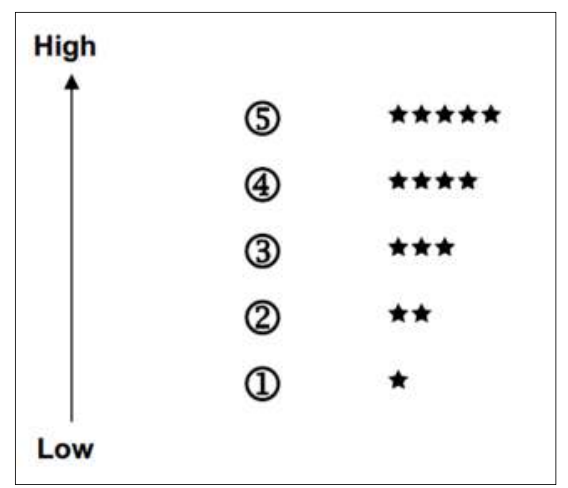

Figure 2. LORI rating scale

\section{RESULTS AND DISCUSSION}

The Web has emerged as an important source of instructional support for writers and writing teachers. Since Purdue University's OWL (online writing lab) moved from its home on Gopher to the World Wide Web in 1994 (OWL Fact Sheet, 2005), a large number of writing centers, writing-across-thecurriculum programs, and composition programs have established presences on the Web (Palmquist, 2005). Web based instruction which has been implemented in teaching Indonesian literacy in Indonesian Language Subject for 8th grader potentialy improve students's curiosity of learning and lead them into enjoyment in writing.

The most common reason that found from students is that web based instruction facilitates social activities, as like as social media. It is very adaptive to be used, because of some adjustment from bassic Moodle template into Facebook template. And also, this type of instruction is rarely to experience in the age of junior high school, and it is new to be implemented in the more structured system. Commonly, students use internet in wide area context as learning resources, not subject to instructional activities. They do some inquiry process to discover solution or contructing argument to be presented in the next meeting. This is quite complicated, whereas they need a guidance from peer or teacher to complete this inquiry process.

\section{Content Quality}

Content quality aspect is measured with three questions that relate to the level of acceptance of students into materials. The questions are:

a) Is the material easy to master?

b) Is the material delivered in common and understandable language

c) Do the examples provided facilitate learning?

From 35 students in a group of classroom, the results score 408 out of $510 \quad(80 \%$ of approriateness). In this level, the students is able to adjust their ability to the prerequisite skills of the lesson. This proves that the web based instruction delivering the material is adapted to the curriculum used by the school. It is predicted to emerge, because the material collected in the platform is the results of need assessment that has been conducted in earlier stage of development by researcher to relevant sources (Indonesian language teacher and vice principal).

Despite of the level of acceptance, students provide some suggestions regarding content quality. Suggestions that often arise from 35 students is the number of samples and materials which should be increased. Learning capability of these students help them to master the material in more efficient time than predicted before. The way they learn individually describes that the cognitive process that they mastered is improved when they are only given guidance to complete the tasks. It is noteable that Teachers should not spend too much time on one piece of writing in the class because this may decrease students' learning motivation and impede them from learning other types of writing (Tangpermpoon. 2008).

\section{Goal Alignment}

The clearness of learning goals are measured with three different sub-aspects, including a) the clarity of objectives, b) relevancy between learning activities and objectives, and c) appropriatness of assignments in achieving objectives. The items are:

d) Are goals and objectives accessible in the platform? 
e) Do the learning activities lead you to comprehend the materials?

f) Does the assignment properly measure the learned materials?

From 35 students in a group of classroom, the results score 399 out of 510 (78\% of approriateness). The statements of goals and objectives are formulated based on instructional programme that the teacher created in the beginning of the semester. The activities experienced by students are constructed based to the goals and objectives, which is appropriate to the curriculum subject.

However, the importance of goals and objective are rarely noticed by students, and they have lack of awareness to what extend that the learning process will lead them. Some assumption arise that the statement of purposes (goals and objectives) are found hard to understand by students. the complexity of formulation $\mathrm{ABCD}$ (Audience, Behaviour, Condition, and Degree) are comparatively abstract to be understood. There is a need to formulate the goals and objectives in a different ways which students are attracted and motivated to achieve them.

\section{Feedback and Adaptation}

The weakness of this protoype is to provide hyper-text analysis to help students composing writing or to check the quality from the gramatically errors. Palmquist (2005) state that students were likely to benefit from tools that corresponded "more directly to cognitive components of the composing process," such as idea organizers, style and grammar checkers, planning and revising prompts embedded within the writing software, communication packages that support peer review, chat, and email, and "artificially intelligent writing environments" that support composing processes and facilitate the analysis of drafts.

The aspect are related to the level adaptiveness of contents or feedback driven by differential learner input of learner modelling. The items are:

a) Does the web based instruction fit you with your learning style?

b) Does quizes help you to understand the lesson?

c) Does feedback provided from teacher and other students help you to improve your writing quality?

From 35 students in a group of classroom, the results score 407 out of 510 ( $80 \%$ of approriateness). The feedback and adaptation provided in the instruction are delivered from discussion forums, quizes, and review of task assignment. Nevertheles, the problem occured when students posted their tasks in form of writing results (e.q. article, poem, verse). There were automatically a big number of writing that suddenly posted in the discussion forum for a short period of time. This caused the students are not able to exercise skimming and scanning process in every writing that must be completed to read. This precisely rise cognitive overload among reading process and unmotivate them to develop the best ideas or evaluation for a writing.

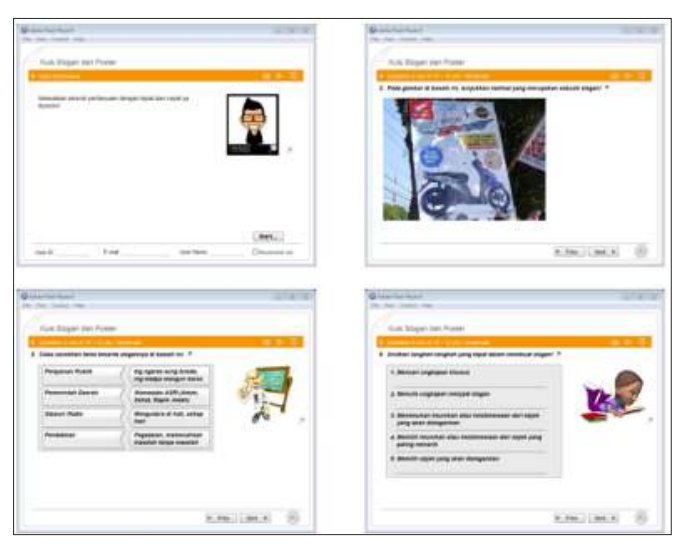

Figure 3. SCORM object interface on quiz

\section{Motivation}

The motivation design in this protoype describe how the web based instruction motivate and interest an identified population of learners based on their learning characteristics. This aspect are asked with two questions as followed:

a) Does web based instruction interest you to learn?

b) Does individual and group activities help you to enjoy the learning process?

From 35 students in a group of classroom, the results score 284 out of $340 \quad(83 \%$ of approriateness). Writing in the product-based approach is viewed as a simple linear model of the writing process which proceeds systematically from prewriting to composing and to correcting (Tribble, 1990). The process of generalization idea, composing draft, and peer correcting is traditional method of writing, but indeed it is scientific proven that has successfully enhanced students writing skill. 


\section{Presentation Design}

Presentation design relates to design of visual and auditory information for enhanced learning and efficient mental processing. This aspect are asked with three questions as followed:

a) Is overal interface of web based instruction easy to be used (user friendly)?

b) Does pictures and images in each sublesson demonstrate the right concept?

c) Does video and audio in each sub-lesson help you to understand the lesson?

From 35 students in a group of classrooom, the results score 406 out of 510 ( $80 \%$ of appropriateness). The quantitiy of multimedia materials are occured to be a problem for students. Most of the students enjoy learning through multimedia files, it gives a clearer explanation about the concepts delivered. Some suggestions from students state that the platform has lack of multimedia materials that can help to generate idea or to stimulate motivation to write.

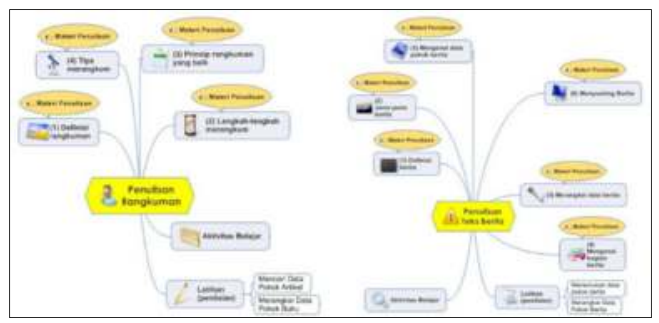

Figure 3. concept maps providing information regarding course structures

\section{Interaction Usability}

Interaction usability is measured the ease of navigation, predictability of the user interface, and quality of the interface help features. This aspect is asked with a single question as followed:

a) Does interface of web provide you easyto-use control both in individual and group learning?

From 35 students in a group of classroom, the results score 139 out of $170 \quad(82 \%$ appropriatness). By working both in individually and in group of pairs, a students improve their not only writing performance but also they improve the social skill, such as discussion, asking a wuestion, explanation, or analyzing skill. Through process of writing, navigation in the interface of web provide the potential benefit that integrate learning resources and forum discussion in the same page. In order to maximize students presence in web based instruction, some suggestions from students have appeared in the following ways. Control of platform should be minimized and adapted to the needs of instruction, therefore the students can focus to complete a specific task in the provided time. It is realized that students are hardly to focus in a specific activity because of a robust of menu button surrounding the main information.

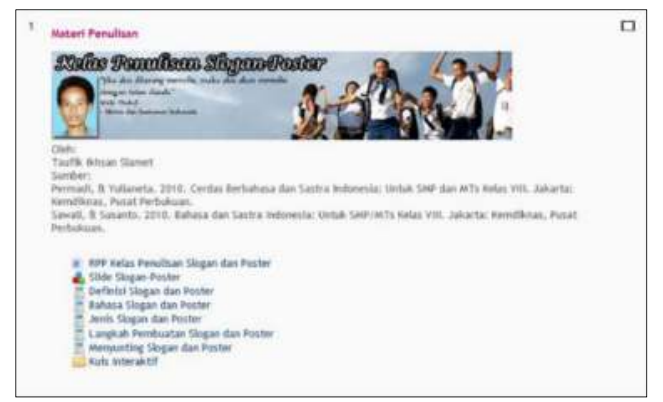

Figure 4. A course structure in web based instruction

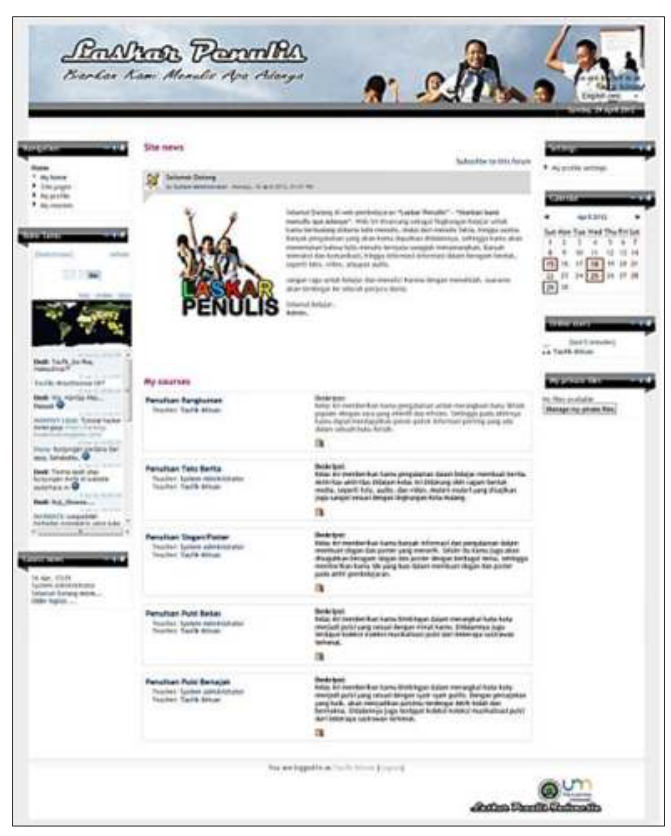

Figure 5. User main page

\section{CONCLUSIONS}

An ideal writing environment would provide student with immediate access during composing to relevant instructional materials and feedback tools (Palmquist, 2005). Interaction, such as comments from teacher or other students, is beneficial for improving 
participation of discussion, excitement of inquiry, motivation to write, and sharing to community. It is easily to find in learning environment, the students interact on their owl style communication. The content in web based instruction has been evaluated for its validity based on schools curriculum, subject teachers, and the needs of the students, that makes this material is adaptive (De Bra,2000;Fletcher,1992; Inan \& Grant, 2008:585). The web based instruction in this subjet is used as suplemental learning materials, which affects to its classroom context teaching and learning (Jones, Haron, \& Lowther, 2003).

Another aspect that is noted as the problem is the evaluation of writing. It is very recomended to give a number of writing practices instead of objective tests. If students tend to be confined to multiple-choice exams with no writing assignments and not even short essay writing in exams. This lack of writing practice is likely to have a strong negative impact on the development of effective writing skills, and probably on the development of content knowledge (Cho \& Schunn, 2007). Importantly, teachers need to set the regulation process of writing and posting. Teachers should avoid students posting all the writings at the same short period of time. They need to excericise the process of skimming and scanning every writing, it might be delivered a couple of wiritng each week, and discuss it in the class. So, every student has their own time to dicuss their writing sistematically.

The strength and weakness of Learning Object framework to evaluate pedagogy infrastructures on web based instruction lies on its comprehensive and broad concept of each aspect. The instrument is likely adaptive to measure pedagogical aspects of web based instruction, but it is difficult to decide whether the item relates to specific aspect of the framework. The factor analysis is highly recomended to assess and construct the instrument more reliable to its results. Further study should be focused to inquire the validity and reliability of the instrument. There is an important need for the instrument to be developed in empirical study.

\section{REFERENCES}

[1] Boyd, D. (2007). Why youth (heart) social network sites: The role of networked publics in teenage social life. MacArthur foundation series on digital learning-Youth, identity, and digital media volume, 119-142.

[2] Cho, K., \& Schunn, C. D. (2007). Scaffolded writing and rewriting in the discipline: A web-based reciprocal peer review system. Computers \& Education, 48(3), 409-426.

[3] Elftorp, F. (2007). How to Improve Students'; Writing and Speaking Skills.

[4] Garrison, D. R. (2007). Online community of inquiry review: Social, cognitive, and teaching presence issues. Journal of Asynchronous Learning Networks, 11(1), 61-72.

[5] Graham, S., \& Perin, D. (2007). A metaanalysis of writing instruction for adolescent students.

[6] Graham, S., \& Perin, D. (2007). Writing Next-Effective strategies to improve writing of adolescents in middle and high schools.

[7] Inan, Fethi, \& M.Grant. 2008. Individualized Web-Based Instructional Design.

Dalam Terry T. Kidd \& Holim Song (Eds.), Handbook of Research on Instructional Systems and Technology Vol.II (hlm 582-595). New York: Information Science Reference.

[8] Jones, M.G., S.W.Harmon, \& D. Lowther. 2002. Integrating Web-Based Learning in An Educational System: A Framework for Implementation. Dalam Reiser, R.A. \& Dempsey, J.V. (Eds), Trends and Issue in Instructional Design and Technology, (p.295-306). Upper Saddle River, New Jersey: Merrill Prentice Hall.

[9] Mak, B., \& Coniam, D. (2008). Using wikis to enhance and develop writing skills among secondary school students in Hong Kong. System, 36(3), 437-455.

[10] McLoughlin, C., \& Lee, M. J. (2007). Social software and participatory learning: Pedagogical choices with technology affordances in the Web 2.0 era. In ICT: Providing choices for learners and learning. Proceedings ascilite Singapore 2007 (pp. 664-675).

[11] Nesbit, J. C., Archambault, A., Belfer, K., \& Vargo, J. (2003). Learning object evaluation: computer-mediated collaboration and inter-rater reliability. 
International Journal of Computers and Applications, 25(3), 198-205.

[12] Rijlaarsdam, G. \& Van den Bergh, H. (2004). Effective learning and teaching of writing:

Student involvement in the teaching of writing. Rijlaarsdam, G. (Series Ed.) \& Rijlaarsdam, G., Van den Bergh, H., \& Couzijn, M. (Vol. Eds.) (2004). Studies in Writing. Vol. 14, Effective Learning and Teaching in Writing, Edition, 1 - 16.

[13] Saada-Robert, M., Balslev, K., \& Mazurczak, K. (2004). Emergent writing in kindergarten and the emergence of the alphabetic principle. In Rijlaarsdam, G. (Series Ed.) \& Rijlaarsdam, G., Van den Bergh, H., \& Couzijn, M. (Vol. Eds.), Studies in writing. Vol. 14, Effective learning and teaching of writing, Edition, Part 1, Studies in learning to write, 17 - 30.

[14] Shih, R.-C. (2011). Can Web 2.0 technology assist college students in learning English writing? Integrating Facebook and peer assessment with blended learning. Australasian Journal of Educational Technology, 27(5). Retrieved from http://ascilite.org.au/ajet/submission/inde x.php/AJET/article/view/934

[15] Tangpermpoon, T. (2008). Integrated approaches to improve students writing skills for English major students. ABAC journal, 28(2).

[16] Tribble, Christopher. (1990). Writing. (pp.37-44). Oxford: Oxford University Press. 